\title{
Confucianism and Firm Performance
}

\author{
Lisong Wang ${ }^{1,2}$, Yongjie Zhang ${ }^{1}$, LiNa Wang ${ }^{3 *}$ and Jingkai Fu ${ }^{4}$ \\ ${ }^{1}$ College of Management and Economics, Tianjin University, Tianjin, China, ${ }^{2}$ School of Foreign Language and \\ Literature, Tianjin University, Tianjin, China, ${ }^{3}$ Department of Finance, School of Economics, Tianjin University of Finance and \\ Economics Pearl River College, Tianjin, China, ${ }^{4}$ Peddie School, Hightstown, NJ, United States
}

This paper examines the impact of Confucianism on firm performance, taking Chinese listed companies from 2000 to 2018 as the research object. The results show that (1) Confucianism provides legitimacy for a company's profit-seeking behavior and therefore helps to improve firm performance; and (2) Confucianism can effectively improve the efficiency of supervision mechanisms but weaken the marginal contribution of incentive mechanisms to financial performance. This paper provides empirical evidence for the influence of Confucianism on firm performance, broadening the understanding of the role of informal institutions in company finance and enriching the theory of "culture and finance."

\section{OPEN ACCESS}

Edited by:

Wei-Xing Zhou,

East China University of Science and

Technology, China

Reviewed by:

Mei Xue,

Boston College, United States

Khalil Jebran,

Dongbei University of Finance and

Economics, China

*Correspondence:

LiNa Wang

wanglina1008@163.com

Specialty section:

This article was submitted to

Social Physics,

a section of the journal

Frontiers in Physics

Received: 13 April 2020

Accepted: 10 July 2020

Published: 21 August 2020

Citation:

Wang L, Zhang Y, Wang L and Fu J (2020) Confucianism and Firm

Performance. Front. Phys. 8:319.

doi: 10.3389/fphy.2020.00319
Keywords: confucianism, firm performance, corporate governance, culture, supervision mechanisms

\section{INTRODUCTION}

In recent years, some studies have shown that in addition to economic factors affecting firm performance, non-economic factors such as culture also play an important role in firm performance $[1,2]$. For China, a transition economy with imperfect institutions and still less efficient law enforcement, informal systems such as culture may play a more important role in firm performance. For the Chinese society, Confucianism is the most far-reaching informal system; it shapes the spirit of Chinese enterprises and may provide important spiritual support in the process of China's modernization. Confucianism is now once again faced with the possibility of rejuvenation in China even after having gone through a century of obstruction, which will absolutely have an effect on all aspects of China's economy [3]. Therefore, by examining the impact of Confucianism on firm performance, this paper attempts to discover how the informal system affects microenterprises and thus boosts China's economy.

It is not common to see empirical research on these issues because there are a series of difficulties and controversies that arise in measuring the impact of culture on economic behavior. Currently, the general methods used to measure culture's effect mainly include the Hofstede index [4], which focuses on the influence of cultures from different countries on individual behavior. This index excludes "benevolence," a main concept of Confucianism, so it is difficult to use the index to objectively reflect the influence of Confucianism on management behavior. In recent years, many scholars have started to use historical data to explain the impact of culture and institutions on financial performance $[5,6]$. Confucianism, a mainstream ideology of ancient China, has accumulated for a long time and has gradually become the criterion the public uses to think about and judge individual behavior. Therefore, it is basically feasible to use historical data to measure Confucianism. After a comprehensive consideration of the above factors, we chose the local records of the Qing Dynasty as the basic data source and found proxy variables that indirectly measure Confucianism. Then, the 
financial data from A-share listed companies from 2000 to 2012 were selected as the sample for the research.

First, this paper studies the impact of Confucianism on firm performance, showing that the greater the impact of Confucianism on a company, the higher its profitability. This statement implies that Confucianism not only legalizes a company's profit-seeking behavior but also contributes to its capital appreciation and wealth creation. Second, the supervision and incentive measures adopted by a company for the purpose of improving profitability are all affected by Confucianism. The empirical results show that Confucianism is conducive to improving the efficiency of supervision while weakening the marginal contribution of the incentive mechanisms to corporate performance.

This paper has two main research contributions. First, it attempts to combine empirical scientific methods with Confucianism and establish a research framework, striving to find a feasible path for empirical research on Confucianism. Second, this paper studies the impact of Confucianism on corporate performance by considering the combination of the reality of Confucianism and corporate governance. The research conclusions are of great theoretical significance not only for academic circles seeking to rediscover Confucianism but also for listed companies in the Chinese cultural context seeking to choose appropriate governance mechanisms and government departments to improve their supervision system.

This paper is arranged as follows: the second part is a literature review and provides the research hypothesis; the third part describes the measurement of variables and sample selection; the fourth part provides the empirical research results; the fifth part presents the robustness test; and the last part provides the conclusion.

\section{LITERATURE REVIEW AND RESEARCH HYPOTHESIS}

\section{Literature Review}

As shown in the literature on corporate finance, culture is defined as the concept and related values of stabilizing intergeneration inheritance through ethnic, religion, and social groups [7]. Byod and Richerson [8] defined culture as "the knowledge, values and other factors that are passed down from generation to generation through education and imitation, and can influence behavior," and claimed that culture has the following functions: (1) culture provides language-based information processing methods; and (2) the ethics derived from a culture help to reduce the cost of contract implementation and can effectively reduce the externality caused by the free rider problem. Guiso et al. [6] claimed that the intergenerational culture would affect the level of trust an individual has with other partners, thus affecting that individual's behavior and financial performance. As a longterm and stable informal institutional arrangement in a specific region, culture may affect the quality of information disclosure [9-11], tax behavior [12], business decision-making [6, 13], and investment behavior $[14,15]$. Similarly, firm performance is also affected by external cultural factors.
Franke et al. [16] conducted an empirical study on cultural and financial performance in 18 countries from 1965 to 1987. The results show that power distance is positively correlated with firm performance, while individualism is negatively correlated with firm performance. Gorodnichenko and Roland [17] used per capita GDP to measure financial performance. The empirical results show that individualism is positively correlated with corporate performance. The above empirical results imply that it is difficult to use the Hofstadter index. In other words, the regression results depend on indicators to measure corporate performance, which makes the results unstable. Doney et al. [18] studied the Hofstadter index and trust level and found that the individualism orientation means that the trust process involves rational calculations, and collectivism means that trust is more predictable. Therefore, from the perspective of trust and firm performance, both individualistic orientation and collectivistic orientation may produce trust and affect corporate performance. Furthermore, the empirical results of Fidrmuc and Marcus [9] show that there is a significant positive correlation between the individualism orientation and corporate performance.

In Chinese history, Confucianism was put forward by Confucius in the Spring and Autumn period and then inherited and developed by Mencius and others in the Warring States period. After Emperor Wu of the Han Dynasty "ousted hundreds of schools and respected Confucianism alone," the combination of Confucianism and feudal monarchy established a set of social ethics and moral norms and became a tool for governors. For a long time, Confucianism has been deeply rooted in Chinese society and become the common people's inadvertently held ethics. Although the relationship between culture and corporate performance has been discussed, there are few studies on Confucianism and corporate performance.

\section{Research Hypothesis}

Traditional Chinese culture, for which Confucianism is the core, has a long history of thousands of years, and it has gradually become an indispensable component of the Chinese humanistic environment. Companies operating in this environment may be affected by Confucianism. Confucianism does not reject wealth and even has positive significance for building wealth. Therefore, the Confucian concept of wealth and the method used for wealth building may affect the company's management behavior and decision-making, so they have a positive significance for improving firm performance. Therefore, the following research hypotheses are proposed:

Hypothesis 1: With all other conditions unchanged, the greater the influence of Confucianism, the higher the profitability of the company.

Prior studies show that formal and informal institutions both impact corporate financial behavior [14]. Jebran et al. [19] examined the monitoring role of institutional ownership in the relationship between social trust and corporate financial behavior. They found that institutional ownership, as a formal governance system, weakens the influence of social trust (informal institution) on corporate financial behavior. 


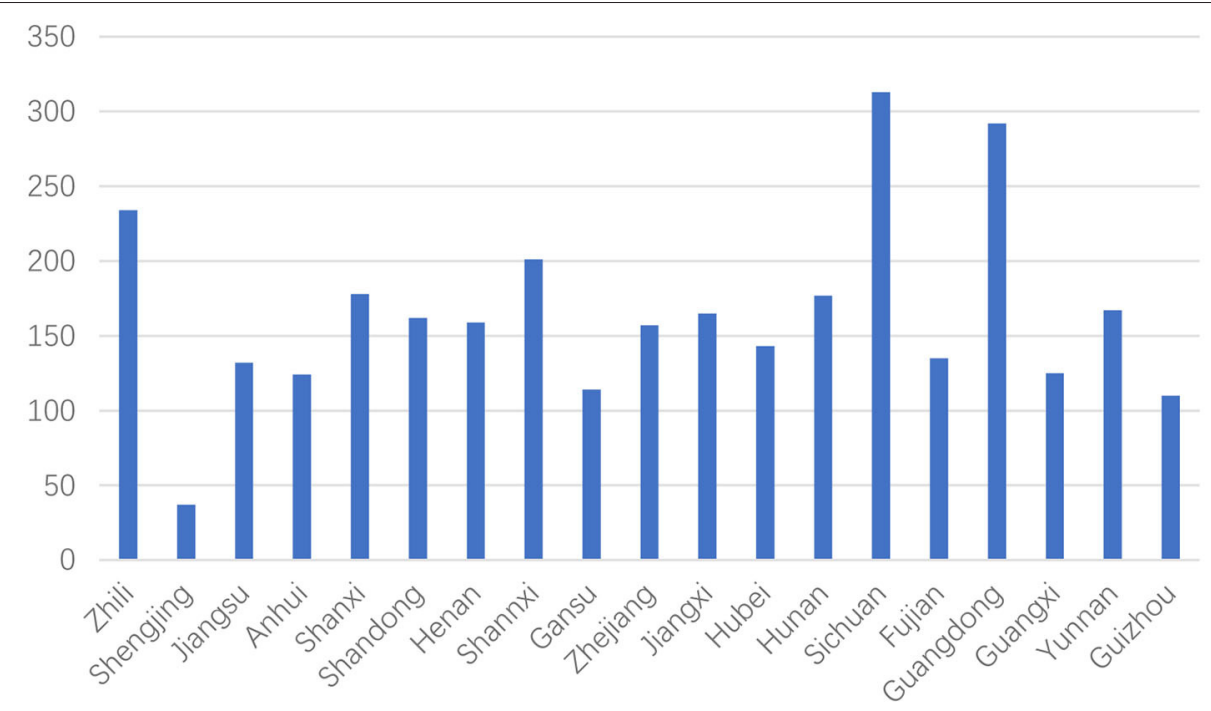

FIGURE 1 | Number of Confucian schools in the provinces of the Qing Dynasty. This figure plots the number of Confucian schools in the provinces of the Qing Dynasty. The horizontal axis represents the provinces, and the vertical axis represents the number of Confucian schools.

In addition, [20] showed that foreign qualified institutional investors can effectively monitor firms.

We conjecture that the influence of Confucianism on firm performance will be weaker when a firm's internal governance mechanism is stronger. We argue that institutional ownership, an internal governance system, can moderate the relationship between Confucianism and firm performance. We assume that greater institutional ownership indicates the use of effective internal governance mechanism and thus informal institutions, such as Confucianism, are less likely to influence corporate decisions. Thus, the following research hypotheses are proposed:

Hypothesis 2: With all other conditions unchanged, the negative association between Confucianism and firm performance is attenuated by institutional ownership.

\section{VARIABLE MEASUREMENT AND SAMPLE SELECTION}

\section{Independent Variable Measurement}

As we all know, the most important feature of Confucianism is that it seeks to improve human behavior through ethical education. Confucian education in the Ming and Qing Dynasties gradually shifted to secularization and popularization. The academy was an important place for Confucian education in the Ming Dynasty. During the Qing Dynasty, official schools and academies laid the foundation for the popularization and spread of Confucian education. In addition to the above historical factors, the choice of attending a Confucian school as a proxy variable was made in light of the following considerations. First, North [21] generalized theory of the system into theory of property rights, theory of the state, and theory of ideology and believed that the role of education was to "instill a set of values repeatedly." Weber [22] claimed that the level of Confucian education was closely related to the quality of education and pointed out that the difference in the distribution of educational institutions represents the strength of Confucian influence.

As mentioned above, Confucian schools are an important source of Confucianism and have gradually developed a common understanding with officials and intellectuals over a long period of time. Therefore, it is impossible to directly measure the influence of Confucianism; however, by using school choice as a proxy variable it is possible to measure the influence of Confucianism. Kwok and Tadesse [23] summarized institutional theory as ownership theory, state theory and ideology theory and believed that the social function of the education system is connected with the inculcation of values. In other words, consistent with the basic theory of institutional economies, we choose Confucian schools as the proxy variable of Confucian influence. Specifically, we choose the local chronicles of the Qing Dynasty as the data source and record the number of official schools (prefectural, state, and county) and academies within the jurisdiction of the provinces, counties, and counties according to the provincial administrative regions of the Qing Dynasty and compare them with those in the jurisdiction of the People's Republic from 1796 to 1840 AD. The statistical results are shown in Figure 1. During this timeframe, 3,284 Confucian educational institutions operated within the scope of the Qing government.

When measuring the influence of culture on a region, usually, two models are used. One is a regional model, and the other is a distance model. Currently, the widely used model is the distance model [24-27]. The greatest advantage of the distance model is that it can use company-level data to determine whether the explanatory variables represent the research object itself, eliminating the influence of other factors. Wines and Napier [28] claimed that the distance model has more advantages than the regional model when considering the 
company or individual level. John et al. [29] used this model to study investment decisions and dividend policies. After a comprehensive consideration of the above factors, we chose the distance model to measure the proxy variable.

The main calculation steps are as follows: First, the longitude and latitude of the listed company are determined by using through the Google Map icon; second, the longitude and latitude of ancient schools (including official schools and colleges) are determined. Finally, we calculate the distance between every listed company and every ancient school according to their respective longitudes and latitudes, following Equations (1-3) shown below.

(i) We define the longitude and latitude of ancient schools (listed companies) as $\omega_{S}$ and $\varphi_{S}\left(\omega_{F}\right.$ and $\left.\varphi_{F}\right)$, respectively. The central angle $(\theta)$ is calculated via the following Equation (1):

$$
\cos \theta=\sin \varphi_{S} \times \sin \varphi_{F}+\cos \varphi_{S} \times \cos \varphi_{F} \times\left(\omega_{S}-\omega_{F}\right)
$$

(ii) We calculate the arc length per radian using the following Equation (2):

$$
\operatorname{Rad}=\frac{40075.04}{360} \times \frac{180}{\pi}
$$

(iii) Note that the distance between two points equals the length of the minor arc across the surface of the earth. Therefore, we calculate the distance between the location of every ancient school and listed company using Equation (3), which is a well-known equation used for GIS, as shown below:

$$
\text { Distance }=\operatorname{rad} \times\left(\frac{\pi}{2}-\arctan \left(\frac{\cos \theta}{\sqrt{1-\cos ^{2} \theta}}\right)\right)
$$

Finally, 100, 200, and $300 \mathrm{~km}$ are utilized as the distance criteria or upper limits to calculate the number of ancient schools and then define the variables School_100, School_200, and School_300, respectively.

\section{Control Variables}

In this paper, the explained variate is firm performance, which is measured by ROA (return on assets). ROA is calculated by dividing EBIT by average total assets and reflects the economic surplus contributed by the company to stakeholders such as shareholders, creditors, and the government.

Based on the studies of Chen et al. [30] and Jebran et al. [19], we add the following control variables to the regression model: board size, board independence, management shareholding, leverage, firm size, liquidity, fixed assets, CEO duality, GDP, and the number of universities. GDP per capita is used to control for the economic development level of the place (province) where the company is registered and is calculated as the logarithm of GDP per capita (lnGDP). Second, the higher education level of Puritans has a larger direct impact on financial performance than ideology [31]. This paper controls for the influence of local higher education by using the number of 211 project universities in

\begin{tabular}{|c|c|c|}
\hline Variable name & Variable definition & Description \\
\hline $\mathrm{ROA}$ & Return on assets of the company & $\begin{array}{l}\text { Earnings before interest and taxes/average total } \\
\text { assets }\end{array}$ \\
\hline Tobin Q & The ratio of market value to replacement value & Market value/total assets \\
\hline INST & Holding proportion of institutional shareholder & Data from CSMAR database \\
\hline Board_size & Broad size & Logarithm of the number of directors \\
\hline Board_ind & Broad independence & The ratio of independent directors to all directors \\
\hline Man_share & Holding proportion of management & Data from CSMAR database \\
\hline Lev & Debt to asset ratio & Data from CSMAR database \\
\hline Firm size & Firm size, measured by natural log of total assets & Data from CSMAR database \\
\hline Liquidity & The average daily return to volume in the past month & Data from CSMAR database \\
\hline Fixed assets & $\begin{array}{l}\text { Fixed assets that are held for the production of goods or services and have a useful } \\
\text { life of more than one fiscal year }\end{array}$ & Data from CSMAR database \\
\hline Duality & $\begin{array}{l}\text { An indicator variable that is equal to } 1 \text { if the } \mathrm{CEO} \text { and the chairman of the board are } \\
\text { the same person, and } 0 \text { otherwise }\end{array}$ & Data from CSMAR database \\
\hline School_100 & Number of schools within $100 \mathrm{~km}$ from the registered address of the company & Measure according to local chronicle \\
\hline School_200 & Number of schools within $200 \mathrm{~km}$ from the registered address of the company & \\
\hline School_300 & Number of schools within $300 \mathrm{~km}$ from the registered address of the company & \\
\hline InGDP & The logarithm of the per capita GDP in the registered province & $\begin{array}{l}\text { Statistics yearbook (Website of National Bureau of } \\
\text { Statistics) http://www.stats.gov.cn/ }\end{array}$ \\
\hline University & Numbers of Project 211 universities in the registered province & $\begin{array}{l}\text { Website of Ministry of Education http://www.moe. } \\
\text { gov.cn/ }\end{array}$ \\
\hline
\end{tabular}
the company's registered place (province). Finally, the influence

TABLE 1 | Definitions and calculations of the variables.

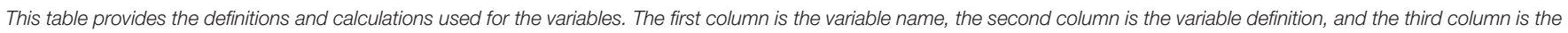
variable description. 
TABLE 2 | Descriptive statistics.

\begin{tabular}{|c|c|c|c|c|c|c|}
\hline Variable name & Sample observation & Mean & Standard deviation & Minimum & Median & Maximum \\
\hline School_100 & 20,121 & 0.122 & 0.049 & 0 & 0.132 & 0.223 \\
\hline School_200 & 20,121 & 0.229 & 0.103 & 0 & 0.242 & 0.505 \\
\hline School_300 & 20,121 & 0.224 & 0.095 & 0 & 0.243 & 0.501 \\
\hline $\mathrm{ROA}$ & 20,121 & 0.053 & 0.052 & -0.363 & 0.027 & 0.831 \\
\hline Tobin Q & 20,121 & 3.231 & 2.478 & 0.435 & 3.125 & 23.742 \\
\hline INST & 20,121 & 0.352 & 0.167 & 0.013 & 0.345 & 0.865 \\
\hline Board_size & 20,121 & 2.008 & 0.196 & 1.055 & 2.132 & 2.677 \\
\hline Board_ind & 20,121 & 0.324 & 0.103 & 0 & 0.232 & 0.600 \\
\hline Man_share & 20,121 & 0.053 & 0.145 & 0 & 0 & 0.687 \\
\hline Lev & 20,121 & 0.423 & 0.187 & 0 & 0.422 & 0.978 \\
\hline Firm size & 20,121 & 21.234 & 25.673 & 19.231 & 21.537 & 24.435 \\
\hline Liquidity & 20,121 & 2.219 & 7.234 & 0.122 & 1.343 & 65.443 \\
\hline Fixed assets & 20,121 & 15.324 & 17.342 & 13.326 & 15.568 & 19.763 \\
\hline Duality & 20,121 & 0.145 & 0.327 & 0 & 0 & 1 \\
\hline InGDP & 20,121 & 10.122 & 0.758 & 0.767 & 9.967 & 10.345 \\
\hline University & 20,121 & 5.656 & 5.764 & 5.456 & 3.879 & 21.994 \\
\hline
\end{tabular}

This table shows the descriptive statistics of the variables. The first column is the variable name, and the second column is the sample observation.

of industry and time also need to be considered [13, 14]; thus, industry and year control variates are added to the regression. Financial data related to corporate performance and governance are all extracted from the CSMAR database. The data sources and calculation methods are shown in Table $\mathbf{1 .}$

\section{Sample Selection}

The sample selected for this empirical study is companies that issued shares and were listed on the Shanghai or Shenzhen Stock Exchanges from 2000 to 2018. After downloading information from the CSMAR database, 22,111 primary samples were obtained, among which were 342 financial industry samples in total, 676 samples with operating incomes less than or equal to 0 or insolvent (leverage $>100 \%$ ), and 972 samples with missing data. After eliminating the above 1990 samples, 20,121 valid samples were obtained, accounting for more than $91 \%$ of the primary samples. See Table 2 for the descriptive statistics of the research variates.

\section{Model}

To test our hypothesis, we consider that firm performance is a function of Confucianism and other control variables. The regression equation is given as follows:

$$
\begin{aligned}
R O A_{i t}= & \beta_{0}+\beta_{1} * \text { School_num } i t+\sum_{q=2}^{m} \beta_{q} * \\
& \left(\text { qth ControlVariable } e_{i t}\right)+\text { Industry }+ \text { Year }+\varepsilon_{i t}
\end{aligned}
$$

where School_num represents the number of schools within 100 kilometers, 200 kilometers, and 300 kilometers of the registered address of firm $i$ at time $t$. We use control variables, mainly including the shareholding ratio of the institutional shareholders (INST), board size (Board_size), board independence (Board_ind), management shareholding ratio
(Man_share), debt-to-asset ratio (Lev), firm size (Firm size), liquidity (Liquidity), fixed assets (Fixed assets), CEO duality (Duality), GDP (lnGDP), and the number of universities (University). $\varepsilon$ is the regression residual.

To test Hypothesis 2, the following regression equation is used in this paper:

$$
\begin{aligned}
R O A_{i t}= & \beta_{0}+\beta_{1} * S c h o o l \_n u m_{i t} * I N S T_{i t}+\sum_{q=2}^{m} \beta_{q}^{*} \\
& \left(\text { qth ControlVariable } e_{i t}\right)+\text { Industry }+ \text { Year }+\varepsilon_{i t}
\end{aligned}
$$

where $I N S T_{i t}$ denotes institutional ownership; the interaction term, School_num $i t * I N S T_{i t}$ captures the moderating effect of institutional ownership; and ControlVariable $e_{i t}$ denotes a set of control variables.

\section{THE EMPIRICAL RESEARCH RESULTS}

Table 3 reports the regression results. The explanatory variable in the first column is School_100, which is the number of schools within 100 kilometers of the registered address of the firm. The regression results show that the coefficient of this variable is 0.0232 , and it is significant at the $1 \%$ confidence level. The explanatory variables in the second and third columns are School_200 and School_300, and the regression coefficients are 0.0132 and 0.0123 , respectively; these are significant at the $1 \%$ confidence level. The above regression results indicate that as Confucian influence increases, firm performance is enhanced. The empirical results support Hypothesis 1.

Table 4 reports the regression results. In the first column, the regression coefficient of the explanatory variable INST is 
TABLE 3 | The impact of Confucianism on firm performance.

\begin{tabular}{|c|c|c|c|}
\hline School_100 & $\begin{array}{c}0.0232^{\star \star \star} \\
(3.98)\end{array}$ & & \\
\hline School_200 & & $\begin{array}{c}0.0132^{\star \star \star} \\
(3.43)\end{array}$ & \\
\hline School_300 & & & $\begin{array}{c}0.0123^{\star \star \star} \\
(3.32)\end{array}$ \\
\hline INST & $\begin{array}{c}0.0354^{\star \star \star} \\
(13.15)\end{array}$ & $\begin{array}{c}0.0381^{\star \star \star} \\
(13.09)\end{array}$ & $\begin{array}{c}0.0351^{\star \star \star} \\
(13.05)\end{array}$ \\
\hline Board_size & $\begin{array}{c}0.0135^{\star \star \star} \\
(7.23)\end{array}$ & $\begin{array}{c}0.0135^{\star \star \star} \\
(7.22)\end{array}$ & $\begin{array}{c}0.0135^{\star \star \star} \\
(7.22)\end{array}$ \\
\hline Board_ind & $\begin{array}{c}0.0131^{\star *} \\
(1.97)\end{array}$ & $\begin{array}{c}0.0146^{\star \star} \\
(2.06)\end{array}$ & $\begin{array}{c}0.0162^{\star \star} \\
(2.05)\end{array}$ \\
\hline Man_share & $\begin{array}{c}0.0306^{\star \star \star} \\
(9.67)\end{array}$ & $\begin{array}{c}0.0312^{\star \star \star} \\
(10.02)\end{array}$ & $\begin{array}{c}0.0318^{\star \star \star} \\
(10.03)\end{array}$ \\
\hline Lev & $\begin{array}{c}-0.0682^{\star * \star} \\
(-27.52)\end{array}$ & $\begin{array}{c}-0.0665^{\star \star \star} \\
(-27.03)\end{array}$ & $\begin{array}{c}-0.0698^{\star \star \star} \\
(-27.35)\end{array}$ \\
\hline Firm size & $\begin{array}{c}0.2313^{\star \star \star} \\
(4.23)\end{array}$ & $\begin{array}{c}0.2412^{\star \star \star} \\
(4.33)\end{array}$ & $\begin{array}{c}0.2431^{\star \star \star} \\
(4.54)\end{array}$ \\
\hline Liquidity & $\begin{array}{c}0.0081 \\
(0.33)\end{array}$ & $\begin{array}{c}0.0103 \\
(0.41)\end{array}$ & $\begin{array}{c}0.0114 \\
(0.42)\end{array}$ \\
\hline Fixed assets & $\begin{array}{c}0.1543 \\
(1.34)\end{array}$ & $\begin{array}{c}0.1632 \\
(1.43)\end{array}$ & $\begin{array}{c}0.1521 \\
(1.25)\end{array}$ \\
\hline Duality & $\begin{array}{c}0.0213 \\
(0.87)\end{array}$ & $\begin{array}{c}0.0204 \\
(0.86)\end{array}$ & $\begin{array}{c}0.0254 \\
(0.91)\end{array}$ \\
\hline InGDP & $\begin{array}{c}0.0056^{\star \star \star} \\
(5.28)\end{array}$ & $\begin{array}{c}0.0055^{\star \star \star} \\
(5.53)\end{array}$ & $\begin{array}{c}0.0052^{\star \star \star} \\
(5.25)\end{array}$ \\
\hline University & $\begin{array}{c}-0.0003^{\star \star \star *} \\
(-4.43)\end{array}$ & $\begin{array}{c}-0.0003^{* \star *} \\
(-4.34)\end{array}$ & $\begin{array}{c}-0.0003^{\text {**x }}(-4.76)\end{array}$ \\
\hline Constant & $\begin{array}{c}-0.0010 \\
(-0.10)\end{array}$ & $\begin{array}{c}-0.0040 \\
(-0.38)\end{array}$ & $\begin{array}{c}-0.0011 \\
(-0.11)\end{array}$ \\
\hline Industry & Control & Control & Control \\
\hline Year & Control & Control & Control \\
\hline$R^{2}(\%)$ & 11.89 & 11.98 & 11.87 \\
\hline Sample capacity & 20,121 & 20,121 & 20,121 \\
\hline F statistic & $81.97^{\star \star \star}$ & $82.94^{\star \star \star}$ & $82.96^{\star \star \star}$ \\
\hline
\end{tabular}

This table shows the impact of Confucianism on firm performance. The dependent variable is ROA, and the main independent variable is School_num (including School_100, School_200, and School_300). The variable definitions are presented in Table 1. We control for industry effects and year effects. The figures in parentheses are $t$-statistics. ${ }^{\star *},{ }^{* * *}$ indicate significance at the 5 , and $1 \%$ confidence levels, respectively.

$0.0316(t=8.59)$, and the regression coefficient of the crossmultiplying term of School_100 and INST is 0.0489 $(t=$ 2.62). The above results imply that as the shareholding ratio of the institutional shareholder increases, firm performance increases, which means that the supervision of the institutional shareholder can effectively improve firm performance. The significant positive correlation between the cross-multiplying term of School_100 and INST and the explanatory variable shows that as Confucian influence increases, institutional shareholder supervision's marginal contribution to financial performance is enhanced. In conclusion, the regression results provided in Table 4 show that the supervision measures taken by the firm's institutional shareholder to improve financial performance are justified according to Confucianism, and Confucianism can effectively improve the efficiency of supervision.
TABLE 4 | Moderating effect of institutional ownership.

\begin{tabular}{|c|c|c|c|}
\hline School_100*INST & $\begin{array}{c}0.0489^{\star \star \star} \\
(2.62)\end{array}$ & & \\
\hline School_200*INST & & $\begin{array}{c}0.0257^{\star \star \star} \\
(2.54)\end{array}$ & \\
\hline School_300*INST & & & $\begin{array}{c}0.1182^{\star \star \star *} \\
(3.50)\end{array}$ \\
\hline INST & $\begin{array}{c}0.0316^{\star \star \star} \\
(8.59)\end{array}$ & $\begin{array}{l}0.0317^{\star \star \star} \\
(8.62)\end{array}$ & $\begin{array}{l}0.0299^{\star \star \star} \\
(8.32)\end{array}$ \\
\hline Board_size & $\begin{array}{c}0.0156^{\star \star \star} \\
(7.24)\end{array}$ & $\begin{array}{c}0.0135^{\star \star \star} \\
(7.12)\end{array}$ & $\begin{array}{c}0.0153^{\star \star \star} \\
(7.21)\end{array}$ \\
\hline Board_ind & $\begin{array}{c}0.0153^{*} \\
(1.92)\end{array}$ & $\begin{array}{c}0.0155^{\star \star} \\
(1.98)\end{array}$ & $\begin{array}{c}0.0151^{* *} \\
(1.99)\end{array}$ \\
\hline Man_share & $\begin{array}{c}0.0312^{\star \star \star} \\
(10.09)\end{array}$ & $\begin{array}{c}0.0321^{\star \star \star} \\
(10.11)\end{array}$ & $\begin{array}{c}0.0320^{\star \star \star} \\
(10.12)\end{array}$ \\
\hline Lev & $\begin{array}{c}-0.0675^{\star \star \star} \\
(-27.02)\end{array}$ & $\begin{array}{c}-0.0675^{\star \star \star} \\
(-27.04)\end{array}$ & $\begin{array}{c}-0.0677^{\star \star \star} \\
(-27.09)\end{array}$ \\
\hline Firm size & $\begin{array}{c}0.2254^{\star * \star} \\
(4.26)\end{array}$ & $\begin{array}{c}0.2389^{\star * *} \\
(4.45)\end{array}$ & $\begin{array}{c}0.2129^{\star \star \star} \\
(4.09)\end{array}$ \\
\hline Liquidity & $\begin{array}{c}0.0102 \\
(0.45)\end{array}$ & $\begin{array}{c}0.0113 \\
(0.48)\end{array}$ & $\begin{array}{c}0.0093 \\
(0.34)\end{array}$ \\
\hline Fixed assets & $\begin{array}{c}0.1432 \\
(1.21)\end{array}$ & $\begin{array}{c}0.1427 \\
(1.19)\end{array}$ & $\begin{array}{c}0.1321 \\
(1.02)\end{array}$ \\
\hline Duality & $\begin{array}{c}0.0243 \\
(0.86)\end{array}$ & $\begin{array}{c}0.0231 \\
(0.81)\end{array}$ & $\begin{array}{c}0.0245 \\
(0.88)\end{array}$ \\
\hline InGDP & $\begin{array}{c}0.0052^{\star \star \star} \\
(5.46)\end{array}$ & $\begin{array}{c}0.0056^{\star \star \star} \\
(5.76)\end{array}$ & $\begin{array}{c}0.0052^{\star \star \star} \\
(5.34)\end{array}$ \\
\hline University & $\begin{array}{c}-0.0003^{\star \star \star} \\
(-4.42)\end{array}$ & $\begin{array}{c}-0.0003^{\star \star \star} \\
(-4.31)\end{array}$ & $\begin{array}{c}-0.0004^{\star \star \star} \\
(-4.46)\end{array}$ \\
\hline Constant & $\begin{array}{c}-0.0011 \\
(-0.10)\end{array}$ & $\begin{array}{c}-0.0028 \\
(-0.29)\end{array}$ & $\begin{array}{c}-0.0011 \\
(-0.12)\end{array}$ \\
\hline Industry & Control & Control & Control \\
\hline Year & Control & Control & Control \\
\hline$R^{2}(\%)$ & 11.87 & 11.76 & 11.98 \\
\hline Sample capacity & 20,121 & 20,121 & 20,121 \\
\hline F statistic & $82.55^{\star \star \star}$ & $82.54^{\star \star \star}$ & $82.65^{\star \star *}$ \\
\hline
\end{tabular}

This table reports the moderating effect of institutional ownership on the relation between Confucianism and firm performance. The variable definitions are presented in Table 1. We control for industry effects and year effects. The figures in parentheses are $t$-statistics. *, **, ${ }^{* * *}$ indicate significance at the 10,5, and $1 \%$ confidence levels, respectively.

\section{ROBUSTNESS TEST}

\section{Alternative Proxy of Confucianism}

To ensure the robustness of the regression results, we conducted the following robustness test; that is, we selected the number of Confucian schools in the provincial administrative areas to replace the corresponding explanatory variables mentioned above and performed another regression. In addition, referring to the studies of $\mathrm{Du}$ [32], Chen et al. [30], Jebran et al. [19], and Chen et al. [30], we measured Confucianism by the distance between a firm's registered address and 7 Confucian centers in China. We calculated the geographical-proximitybased Confucianism, $\mathrm{CONF}_{N}$

$$
C O N F_{N}=\frac{\operatorname{MaxDIS}_{N}-D I S_{N}}{M a x D I S_{N}-\operatorname{MinDIS}_{N}}
$$


TABLE 5 | Robustness test: independent variables School_pro and CONF.

\begin{tabular}{|c|c|c|c|c|}
\hline School_pro & $\begin{array}{c}0.0362^{\star \star \star} \\
(6.35)\end{array}$ & & & \\
\hline School_pro*INST & & $\begin{array}{c}0.0819^{\star \star \star} \\
(6.12)\end{array}$ & & \\
\hline $\mathrm{CONF}_{\mathrm{N}}$ & & & $\begin{array}{c}0.1534^{\star *} \\
(2.34)\end{array}$ & \\
\hline $\mathrm{CONF}_{\mathrm{N}}^{*} \mathrm{INST}$ & & & & $\begin{array}{c}0.3212^{\star \star} \\
(2.56)\end{array}$ \\
\hline INST & $\begin{array}{c}0.0369^{\star \star \star} \\
(13.25)\end{array}$ & $\begin{array}{c}0.0272^{\star \star \star} \\
(8.21)\end{array}$ & $\begin{array}{c}0.0432^{\star \star \star} \\
(14.43)\end{array}$ & $\begin{array}{c}0.0532^{\star \star \star} \\
(15.23)\end{array}$ \\
\hline Board_size & $\begin{array}{c}0.0153^{\star \star \star} \\
(7.19)\end{array}$ & $\begin{array}{c}0.0159^{\star * \star} \\
(7.50)\end{array}$ & $\begin{array}{c}0.0231^{\star \star \star} \\
(5.21)\end{array}$ & $\begin{array}{c}0.0224^{\star \star \star} \\
(4.51)\end{array}$ \\
\hline Board_ind & $\begin{array}{c}0.0135^{*} \\
(1.78)\end{array}$ & $\begin{array}{c}0.0142^{*} \\
(1.87)\end{array}$ & $\begin{array}{c}0.0231^{\star \star} \\
(2.31)\end{array}$ & $\begin{array}{c}0.0257^{\star \star \star} \\
(2.58)\end{array}$ \\
\hline Man_share & $\begin{array}{c}0.0303^{\star \star \star} \\
(9.55)\end{array}$ & $\begin{array}{c}0.0309^{\star \star \star} \\
(9.66)\end{array}$ & $\begin{array}{c}0.0231^{\star \star \star} \\
(4.87)\end{array}$ & $\begin{array}{c}0.0203^{\star \star \star} \\
(4.43)\end{array}$ \\
\hline Lev & $\begin{array}{c}-0.0673^{\star \star \star} \\
(-26.87)\end{array}$ & $\begin{array}{c}-0.0656^{\star \star \star} \\
(-26.32)\end{array}$ & $\begin{array}{c}-0.0532^{* \star \star} \\
(-17.73)\end{array}$ & $\begin{array}{c}-0.0521^{\star \star \star} \\
(-16.33)\end{array}$ \\
\hline Firm size & $\begin{array}{c}0.2413^{\star \star \star} \\
(4.23)\end{array}$ & $\begin{array}{c}0.2132^{\star \star \star} \\
(3.81)\end{array}$ & $\begin{array}{c}0.2768^{* \star \star} \\
(5.42)\end{array}$ & $\begin{array}{c}0.2543^{\star \star \star} \\
(5.05)\end{array}$ \\
\hline Liquidity & $0(0.12)$ & $\begin{array}{c}0.0023 \\
(0.14)\end{array}$ & $\begin{array}{c}0.0124 \\
(0.54)\end{array}$ & $\begin{array}{c}0.0321 \\
(1.32)\end{array}$ \\
\hline Fixed assets & $\begin{array}{c}0.1922^{*} \\
(1.68)\end{array}$ & $\begin{array}{c}0.2065^{*} \\
(1.73)\end{array}$ & $\begin{array}{c}0.2013^{*} \\
(1.73)\end{array}$ & $\begin{array}{c}0.1987^{*} \\
(1.66)\end{array}$ \\
\hline Duality & $\begin{array}{c}0.0312 \\
(0.95)\end{array}$ & $\begin{array}{c}0.0324 \\
(1.01)\end{array}$ & $\begin{array}{c}0.0214 \\
(0.75)\end{array}$ & $\begin{array}{c}0.0321 \\
(0.87)\end{array}$ \\
\hline InGDP & $\begin{array}{c}0.0072^{\star * \star} \\
(7.29)\end{array}$ & $\begin{array}{c}0.0073^{\star \star *} \\
(7.30)\end{array}$ & $\begin{array}{c}0.0123^{\star \star \star} \\
(6.62)\end{array}$ & $\begin{array}{c}0.0121^{\star * \star} \\
(6.53)\end{array}$ \\
\hline University & $\begin{array}{c}-0.0003^{\star \star \star} \\
(-3.24)\end{array}$ & $\begin{array}{c}-0.0005^{\star \star \star} \\
(-3.25)\end{array}$ & $\begin{array}{c}-0.0032^{\star \star \star} \\
(-4.65)\end{array}$ & $\begin{array}{c}-0.0023^{\star \star \star} \\
(-3.32)\end{array}$ \\
\hline Constant & $\begin{array}{c}-0.0231^{\star \star} \\
(-2.31)\end{array}$ & $\begin{array}{c}-0.0157^{\star} \\
(-1.65)\end{array}$ & $\begin{array}{c}-0.0356^{\star \star \star} \\
(-3.32)\end{array}$ & $\begin{array}{c}-0.0457^{\star \star \star} \\
(-4.25)\end{array}$ \\
\hline Industry & Control & Control & Control & Control \\
\hline Year & Control & Control & Control & Control \\
\hline$R^{2}(\%)$ & 12.09 & 12.13 & 9.09 & 12.12 \\
\hline Sample capacity & 20,121 & 20,121 & 20,121 & 20,121 \\
\hline F statistic & $83.79^{\star \star \star}$ & $81.15^{\star \star \star}$ & $74.21^{\star \star \star}$ & $81.59^{\star \star \star}$ \\
\hline
\end{tabular}

This table shows the results of the robustness test. The dependent variable is ROA, and the main independent variables are School_pro and CONF. The variable definitions are presented in Table 1. We control for industry effects and year effects. The figures in parentheses are $t$-statistics. ${ }^{*},{ }^{* *},{ }^{* \star *}$ indicate significance at the 10, 5, and $1 \%$ confidence levels, respectively.

where $\mathrm{N}$ denotes 7 Confucianism centers; $D I S_{N}$ denotes the distance between the firm and Confucianism center N; $\operatorname{MaxDIS}_{N}$ and $\operatorname{MinDIS}_{N}$ represent the maximum and minimum values, respectively, of $D I S_{N}$ for all firms by year. The regression results are shown in Table 5.

The explanatory variable in columns (1) and (2) of Table 5 is the total number of schools in the provincial administrative areas. By observing the regression results, it is not difficult to find that the number of schools in the provincial administrative areas School_pro is significantly positively correlated with the dependent variable and passes the significance test at the $1 \%$ confidence level. Similarly, the cross-product terms of School_pro and supervision mechanism are significantly positively correlated with the explained variables, and both pass
TABLE 6 | Robustness test: dependent variable Tobin Q.

\begin{tabular}{|c|c|c|c|}
\hline School_100 & $\begin{array}{c}2.3213^{\star \star \star} \\
(3.32)\end{array}$ & & \\
\hline School_200 & & $\begin{array}{c}2.7625^{\star \star \star} \\
(3.54)\end{array}$ & \\
\hline School_300 & & & $\begin{array}{c}2.3342^{\star \star \star} \\
(3.26)\end{array}$ \\
\hline INST & $\begin{array}{c}0.5634^{\star \star \star} \\
(9.21)\end{array}$ & $\begin{array}{c}0.5472^{\star \star \star} \\
(8.09)\end{array}$ & $\begin{array}{c}0.4281^{\star * \star} \\
(6.05)\end{array}$ \\
\hline Board_size & $\begin{array}{c}0.1321^{\star \star \star} \\
(4.24)\end{array}$ & $\begin{array}{c}0.1353^{\star \star \star} \\
(4.65)\end{array}$ & $\begin{array}{c}0.1224^{\star \star \star} \\
(4.17)\end{array}$ \\
\hline Board_ind & $\begin{array}{c}0.6534 \\
(1.55)\end{array}$ & $\begin{array}{c}0.4623 \\
(1.16)\end{array}$ & $\begin{array}{c}0.4322 \\
(1.12)\end{array}$ \\
\hline Man_share & $\begin{array}{c}0.1282^{\star \star \star} \\
(4.03)\end{array}$ & $\begin{array}{c}0.1321^{\star \star \star} \\
(4.21)\end{array}$ & $\begin{array}{c}0.1223^{\star \star \star} \\
(3.86)\end{array}$ \\
\hline Lev & $\begin{array}{c}-0.2721^{\star \star \star} \\
(-17.24)\end{array}$ & $\begin{array}{c}-0.2323^{\star \star *} \\
(-15.03)\end{array}$ & $\begin{array}{c}-0.2431^{\star \star \star} \\
(-16.32)\end{array}$ \\
\hline Firm size & $\begin{array}{c}0.4323^{\star \star \star} \\
(3.24)\end{array}$ & $\begin{array}{c}0.4873^{\star \star \star} \\
(3.54)\end{array}$ & $\begin{array}{c}0.4313^{\star \star \star} \\
(3.27)\end{array}$ \\
\hline Liquidity & $\begin{array}{c}0.0112 \\
(0.32)\end{array}$ & $\begin{array}{c}0.0134 \\
(0.35)\end{array}$ & $\begin{array}{c}0.0105 \\
(0.32)\end{array}$ \\
\hline Fixed assets & $\begin{array}{l}0.2341 \\
(1.20)\end{array}$ & $\begin{array}{c}0.2512 \\
(1.53)\end{array}$ & $\begin{array}{c}0.2132 \\
(1.12)\end{array}$ \\
\hline Duality & $\begin{array}{c}0.1321 \\
(0.37)\end{array}$ & $\begin{array}{c}0.1043 \\
(0.26)\end{array}$ & $\begin{array}{c}0.1546 \\
(0.51)\end{array}$ \\
\hline InGDP & $\begin{array}{c}0.0323^{\star \star \star} \\
(4.12)\end{array}$ & $\begin{array}{c}0.0344^{\star \star \star} \\
(4.53)\end{array}$ & $\begin{array}{c}0.0422^{\star \star \star} \\
(5.21)\end{array}$ \\
\hline University & $\begin{array}{c}-0.0011^{\star * *} \\
(-3.21)\end{array}$ & $\begin{array}{c}-0.0013^{\star \star *} \\
(-3.34)\end{array}$ & $\begin{array}{c}-0.0010^{\star \star \star *} \\
(-3.06)\end{array}$ \\
\hline Constant & $\begin{array}{c}-0.0234 \\
(-0.12)\end{array}$ & $\begin{array}{c}-0.0543 \\
(-0.28)\end{array}$ & $\begin{array}{c}-0.0312 \\
(-0.21)\end{array}$ \\
\hline Industry & Control & Control & Control \\
\hline Year & Control & Control & Control \\
\hline$R^{2}(\%)$ & 14.23 & 14.28 & 13.67 \\
\hline Sample capacity & 20,121 & 20,121 & 20,121 \\
\hline F statistic & $88.21^{\star \star \star}$ & $86.44^{\star \star \star}$ & $85.45^{\star \star \star}$ \\
\hline
\end{tabular}

This table shows the results of robustness test. The dependent variable is Tobin $Q$, and the main independent variable is the School_num (including School_100, School_200, and School_300). Variable definitions are presented in Table 1. We also control the industry effect and the year effect. Figures in parentheses are $t$-statistics. ${ }^{* *}$ are significant at $1 \%$ confidence level.

the significance test the $1 \%$ confidence level. In addition, we measure Confucianism by the distance between the registered address of the company and the seven Confucian centers in China. The regression results are shown in columns (3) and (4) of Table 5 and are similar to the previous regression results. $\mathrm{CONF}_{\mathrm{N}}$ is significantly positively correlated with the dependent variable. Similarly, the cross-product terms of $\mathrm{CONF}_{\mathrm{N}}$ and INST are significantly positively correlated with the dependent variable.

\section{Alternative Proxy of Firm Performance}

To ensure the robustness of the model, we use Tobin Q as a substitute of ROA and repeat the above regression to measure the influence of Confucianism on firm performance. The regression results are shown in Table 6.

The regression results showed that the coefficients of the independent variables (school_100, shool_200, and school_300) 
are all significant at the $1 \%$ confidence level, indicating that firm performance increases with the increasing influence of Confucianism; this result is similar to the results shown in Table 3.

We also carried out additional robustness tests by (1) replacing the explained variable ROA with the industry-adjusted ROA, that is, considering the influence of industry factors; and (2) considering the impact of the financial crisis; that is, the timeframe of the study was divided into two periods, 2000-2007 and 2008-2012. The results of these tests are very similar to the previous regression results. Due to space limitations, we do not report the results of these tests.

\section{CONCLUSION}

This paper examines the impact of Confucianism on firm performance, taking Chinese listed companies from 2000 to 2018 as the research object. The following conclusions are obtained. (1) Confucianism provides legitimacy for the company's profit-seeking behavior and therefore helps to improve firm performance. (2) Confucianism can effectively improve the efficiency of supervision mechanisms but weakens

\section{REFERENCES}

1. Licht AN, Goldschmidt C, Schwartz SH. Culture rules: the foundations of the rule of law and other norms of governance. J Compar Econ. (2007) 35:659-88. doi: 10.1016/j.jce.2007.09.001

2. Li K, Griffin D, Yue H, Zhao L. How does culture influence corporate risk-taking. J Corporate Finance. (2013) 23:1-22. doi: 10.1016/j.jcorpfin.2013.07.008

3. Hofstede G. Culture's Consequences: Comparing Values, Behaviors, Institutions, and Organizations Across Nations. London: SAGE Publications Inc. (2001)

4. Hofstede G. Culture's Consequences: International Differences in Work-Related Values. Los Angeles, CA: SAGE Publications Inc. (1980).

5. La Porta R, Lopez-de-Silanes F, Shleifer A, Vishny R. Law and finance. J Polit Econ. (1998) 106:1113-55. doi: 10.1086/250042

6. Guiso L, Zingale L, Sapicnz P. Social capital as good culture. J Eur Econ Assoc. (2008) 6:295-320. doi: 10.1162/JEEA.2008.6.2-3.295

7. Hope OK. Firm-level disclosures and the relative roles of culture and legal origin. J Int Financial Manage Account. (2003) 14:218-48. doi: 10.1111/1467-646X.00097

8. Boyd R, Richerson PJ. Culture and the Evolutionary Process. Chicago: University of Chicago Press (1985).

9. Fidrmuc JP, Marcus J. Culture, agency costs, and dividends. J Compar Econ. (2010) 38:321-39. doi: 10.1016/j.jce.2010.04.002

10. Kung JK, Ma C. Can cultural norms reduce conflicts? Confucianism and peasant rebellions in Qing China. J Dev Econ. (2014) 111:132-49. doi: 10.1016/j.jdeveco.2014.08.006

11. Braguinsky S, Mityakov S. Foreign corporations and the culture of transparency: evidence from Russian administrative data. $J$ Financial Econ. (2015) 117:139-64. doi: 10.1016/j.jfineco.2013. 02.016

12. DeBacker J, Heim BT, Tran A. Importing corruption culture from overseas: evidence from corporate tax evasion in the United States. J Financial Econ. (2015) 117:122-38. doi: 10.1016/j.jfineco.2012.11.009

13. Hilary G, Hui KW. Does religion matter in corporate decision making in America? J Financial Econ. (2009) 93:455-73. doi: 10.1016/j.jfineco.2008.10.001 the marginal contribution of incentive mechanisms to financial performance. This paper provides empirical evidence on the influence of Confucianism on firm performance, broadening the understanding of the role of informal institutions in company finance and enriching theory on "culture and finance."

\section{DATA AVAILABILITY STATEMENT}

The original contributions presented in the study are included in the article/supplementary material, further inquiries can be directed to the corresponding author.

\section{AUTHOR CONTRIBUTIONS}

All authors listed have made a substantial, direct and intellectual contribution to the work, and approved it for publication.

\section{FUNDING}

This work was partly supported by Philosophy and Social Science Planning Project of Tianjin (Grant No. TJYY19XSX-017) and the National Natural Science Foundation of China (71771170).

14. Du X. Does confucianism reduce board gender diversity? Firm-level evidence from China. J Business Ethics. (2016) 136:399-436. doi: 10.1007/s10551-0142508-x

15. Cardoso FM, Meloni S, Santanche A, Moreno Y. Topical alignment in online social systems. Front Phys. (2019) 7:58. doi: 10.3389/fphy.2019. 00058

16. Franke RH, Hofstede G, Bond MH. Cultural roots of economic performance: a research note. Strat Manage J. (1991) 12:165-73. doi: 10.1002/smj.4250120912

17. Gorodnichenko Y, Roland G. Culture, Institutions and the Wealth of Nations. NBER Working Paper, No. 16368 (2010).

18. Doney PM, Cannon JP, Mullen MR. Understanding of the influence of national culture on the development of trust. Acad Manage Rev. (1998) 23:601-20. doi: 10.5465/amr.1998.926629

19. Jebran K, Chen S, Ye Y, Wang C. Confucianism and stock price crash risk: evidence from China. North Am J Econ Finance. (2019) 50:100995. doi: 10.1016/j.najef.2019.100995

20. Cao C, Xia C, Chan KC. Social trust and stock price crash risk: evidence from China. Int Rev Econ Finance. (2016) 46:148-65. doi: 10.1016/j.iref.2016.09.003

21. North DC. Structure and Change in Economic History. Beijing: The Commercial Press (2002).

22. Weber M. The Religion of China. Wilmington, IL: The Free Press (1951).

23. Kwok CCY, Tadesse S. National culture and financial systems. J Int Business Stud. (2006) 37:227-47. doi: 10.1057/palgrave.jibs.8400188

24. Grinblatt M, Keloharju M. How distance, language, and culture influence stockholdings and trades. J Finance. (2001) 56:1053-73. doi: 10.1111/0022-1082.00355

25. Almog A, Bird R, Garlaschelli D. Enhanced gravity model of trade: reconciling macroeconomic and network models. Front Phys. (2019) 7:55. doi: 10.3389/fphy.2019.00055

26. Kashyap R. The perfect marriage and much more: combining dimension reduction, distance measures and covariance. Phys A Stat Mech Appl. (2019) 536:120938. doi: 10.1016/j.physa.2019.04.174

27. Jiang ZQ, Zhou WX. Multifractal detrending moving average cross-correlation analysis. Phys Rev E. (2011) 84:016106. doi: 10.1103/PhysRevE.84.016106

28. Wines WA, Napier NK. Toward an understanding of cross-cultural ethics: a tentative model. J Business Ethics. (1992) 11:831-41. doi: 10.1007/BF00872361 
29. John K, Knyazeva A, Knyazeva D. Does geography matter? Firm location and corporate payout policy. J Financial Econ. (2011) 101:533-51. doi: 10.1016/j.jfineco.2011.03.014

30. Chen S, Ye Y, Jebran K. Does confucianism reduce corporate overinvestment? Evidence from China. Asia Pac J Financial Stud. (2019) 48:21035. doi: 10.1111/ajfs.12254

31. Becker SO, Woessmann BL. Was weber wrong? a human capital theory of protestant economic history. Q J Econ. (2009) 124:531-96.

32. Du X. Does confucianism reduce minority shareholder expropriation? Evidence from China. J Business Ethics. (2015) 132:661-716. doi: 10.1007/s10551-014-2325-2
Conflict of Interest: The authors declare that the research was conducted in the absence of any commercial or financial relationships that could be construed as a potential conflict of interest.

Copyright (c) 2020 Wang, Zhang, Wang and Fu. This is an open-access article distributed under the terms of the Creative Commons Attribution License (CC BY). The use, distribution or reproduction in other forums is permitted, provided the original author(s) and the copyright owner(s) are credited and that the original publication in this journal is cited, in accordance with accepted academic practice. No use, distribution or reproduction is permitted which does not comply with these terms. 